\title{
Identifikasi Kemampuan Mahasiswa dalam Praktek Mengajar pada Mata Kuliah Teaching English as a Foreign Language (TEFL)
}

\author{
Destina Kasriyati $^{1]}$, Herdi ${ }^{2]}$, M. Fadhly Farhy Abbas ${ }^{3]}$ \\ Universitas Lancang Kuning \\ E-mail: ${ }^{1)}$ destina@unilak.ac.id \\ ${ }^{2}$ herdi@unilak.ac.id \\ 3)fadhly@unilak.ac.id
}

\begin{abstract}
Abstrak
Bahasa Inggris sebagai bahasa asing bagi pemelajar Indonesia, meskipun bahasa Inggris sebagai bahasa asing, mahasiswa bahasa Inggris harus memahami semua mata pelajaran yang diberikan dalam program studi mereka. Ibaratnya TEFL (Teaching English as a Foreign Language) merupakan mata kuliah wajib yang harus diperoleh mahasiswa semester 6 di Fakultas Keguruan dan Ilmu Pendidikan (FKIP) Uniersitas Lancang Kuning (UNILAK) sebelum mahasiswa calon guru praktik mengajar di sekolah pada semester 7 . Penelitian ini bertujuan untuk mengidentifikasi kemampuan siswa dalam mengajar di mata kuliah TEFL. Penelitian ini menggunakan metode penelitian deskriptif kualitatif. Hasil dari penelitian ini adalah kemampuan siswa dalam keterampilan mengajar dikategorikan baik pada pra pembelajaran yaitu sebesar $29 \%$ dapat dikategorikan baik. Pra pembelajaran meliputi cara membuka kelas dengan baik, memberikan salam, memeriksa kehadiran siswa dan memberikan pemanasan. Sedangkan kategori sedang yaitu pada keterampilan menutup yaitu sekitar 23\%. Keterampilan penutup meliputi, kemampuan siswa bahasa Inggris dalam menyimpulkan materi, memberikan umpan balik. Sedangkan untuk kegiatan inti sebesar $24 \%$ meliputi kemampuan siswa dalam menjelaskan materi, mengelola kegiatan kelas, dan memberikan minat siswa. Dapat disimpulkan bahwa kemampuan siswa dalam keterampilan mengajar dikategorikan baik di semua komponen, siswa bahasa Inggris mampu memahami aktivitas- aktivitas di dalam keterampilan mengajar.
\end{abstract}

Kata Kunci: Kemampuan mahasiswa, praktek mengajar, mata kuliah TEFL

\section{Identifying Students' Ability in Teaching Practice on the Course of Teaching English as a Foreign Language}

\begin{abstract}
English as foreign language for Indonesian Learners, although English as foreign language, English students have to comprehend all the subjects that provided in their program study. It is like TEFL (Teaching English as a Foreign Language) is a compulsory subject that must be obtained by 6th semester students at the Faculty of Teacher Training and Education before students who are prospective teachers practice teaching at schools in semester 7. This research aims at identifying students' abilities in teaching in TEFL courses. This research used a qualitative descriptive research method. The result of this research was students' ability in teaching skill was categorized into good in pre-learning, that was $29 \%$, it could be categorized as good. Pre-learning included how to open the class well, giving greetings, checking students' attendance and giving warming up. On the other hand, the moderate category, namely in closing skills, which was around 23\%. Closing skills included, english students' ability in concluding matery, giving feedback. While for core activities is $24 \%$, and
\end{abstract}


it was included students' ability in explaining matery, managing the class activities, and giving students' interested. It can be concluded that the students' ability in teaching skills is categorized as good in all components, English students able to comprehend the component activities in teaching skill.

Keywords: Students' ability, teaching practice, TEFL course

\section{PENDAHULUAN}

Pembangunan nasional Indonesia pada hakikatnya adalah membangun manusia Indonesia seutuhnya. Artinya, tujuan pembangunan Indonesia tidak hanya tercermin dalam bentuk fasilitas, tetapi juga kualitas sumber daya manusia (SDM). Salah satu cara untuk meningkatkan kualitas sumber daya manusia di Indonesia adalah melalui pendidikan. Pendidikan bertujuan untuk mencerdaskan anak bangsa sesuai dengan salah satu tujuan pendidikan nasional yang tertuang dalam Pembukaan UUD 1945 yaitu mencerdaskan kehidupan bangsa. Sangat penting untuk memajukan masyarakat yang cerdas di era ini.

Pendidikan merupakan salah satu upaya untuk mencapai tujuan pendidikan nasional, dan merupakan investasi jangka panjang sumber daya manusia yang memiliki nilai strategis bagi kelangsungan peradaban manusia di dunia. Hal ini erat kaitannya sebagai calon guru sebagai sumber daya manuasia yang dapat mewujudkan peserta didik yang cerdas sehingga calon guru harus mampu mengembangkan keterampilan pengelolaan kelas, calon guru dapat mengembangkan keterampilan pengelolaan kelas selama proses dan mengembangkannya dalam bentuk Rencana Pelaksanaan Pembelajaran (RPP).

Mengajarkan atau memberikan materi atau ilmu adalah tugas seorang guru, tetapi guru juga dituntut mampu mendidik karakter siswa. Sejauh ini, proses pelaporan peningkatan kualitas profesional calon guru sebelum pendaftaran dilakukan melalui mata kuliah micro teaching. Pembelajaran Teaching English as a Foreign Language (TEFL) merupakan metode pembelajaran berbasis kinerja yang menggunakan keterampilan mengajar, penguasaan materi, manajemen siswa, dan manajemen waktu. Hal ini sejalan dengan tugas dan kewajiban guru yang memiliki kepribadian, kemampuan mengajar, keterampilan profesional dan keterampilan sosial. Hal ini berdasarkan ketentuan UU No. 14 Tahun 2005 dan UU No. 19 Tahun 2005.

Sementara itu, menurut UndangUndang Nomor 14 Tahun 2005 tentang Guru dan Dosen, guru harus memiliki empat kompetensi utama. Keempat kompetensi tersebut adalah pendidikan, profesional, kepribadian dan sosial. Guru harus mengimplementasikan keempat kompetensi tersebut dalam pengajaran di sekolah agar pembelajaran dapat berjalan dengan lancar. Ketika calon guru memperoleh teori mengajar dalam perkuliahannya, mereka perlu menerapkannya agar memahami keterampilan mengajar yang harus dikuasai calon guru.

Menurut Shoffa (2017) dan Helmiati (2013), keterampilan dasar mengajar terdiri dari delapan yaitu yang pertama keterampilan membuka dan menutup pelajaran; yang kedua keterampilan menjelaskan pelajaran; yang ketiga keterampilan bertanya; keempat keterampilan mengadakan variasi; kelima keterampilan memberikan penguatan; keenam keterampilan mengelola kelas; ketujuh, keterampilan mengajar kelompok kecil dan perseorangan; yang kedelapan yaitu keterampilan memimpin diskusi kelompok kecil. Menurut Uno (2012), guru yang memiliki kompetensi profesional harus menguasai: 1) Disiplin ilmu pengetahuan sebagai sumber bahan ajar yang akan 
diajarkan, 2) Pengetahuan mengenai karakteristik siswa, 3) Pengetahuan mengenai filsafat dan tujuan pendidikan, 4) Penguasaan metode dan model pembelajaran, 5) Pengetahuan mengenai prinsip-prinsip teknologi pembelajaran, 6) Pengetahuan mengenai penilaian siswa, 7) Pengetahuan mengenai merencanakan dan menguasai kelas guna kelancaran proses pendidikan.

Kemampuan guru meliputi kepribadian, kemampuan mengajar, kemampuan profesional dan kemampuan sosial. Oleh karena itu, calon guru memiliki kemampuan dan keterampilan untuk menjadikan mereka calon guru yang profesional. Mata kuliah TEFL adalah cara yang bagus untuk mengembangkan keterampilan dan kepercayaan diri, mempraktikkan gaya mengajar, dan belajar dan berlatih untuk memberikan umpan balik yang konstruktif kepada siswa. Sesuai dengan tujuan micro teaching, pembelajaran adalah untuk meningkatkan kemampuan proses pembelajaran atau kemampuan profesional calon guru, dan meningkatkan kemampuan pendidik dalam keterampilan tertentu.

Pada mata kuliah Teaching English as a Foreign Language yang menjadi mata kuliah wajib yang harus diikuti oleh mahasiswa sebelum praktek mengajar di sekolah. Selain mata kuliah TEFL terdapat mata kuliah Micro Teaching, yang memiliki tujuan yaitu untuk memberikan kemampuan dan teori menjadi seorang guru yang professional. Untuk mengetahui kemampuan mahasiswa menjadi calon guru, peneliti berharap dapat melihat dan menganalisis kemampuan mahasiswa dalam sistem manajemen kelas mata kuliah TEFL.

Penelitian ini memiliki tujuan untuk memberikan atau analisis kemampuan mahasiswa pada mata kuliah TEFL sebelum calon guru menjadi guru yang sesungguhnya di sekolah. Teaching English as a Foreign Language (TEFL) sangat membantu mahasiswa dalam mempersiapkan diri untuk menjadi guru yang sesungguhnya. Dimana calon guru harus mampu menguasai materi yang akan diajarkan dan mampu melihat kondisi kelas sebelum mengajar di dalam kelas. Banyak persiapan yang harus dilakukan seperti media pembelajaran dan kesiapan mental.

\section{METODE}

Penelitian ini menggunakan metode deskriptif kualitatif. Hal ini bertujuan untuk menggambarkan kemampuan siswa dalam mengelola kelas micro teaching di semester 6 pada program studi pendidikan bahasa Inggris. Penelitian ini dibagi menjadi tiga tahap, tahap pertama penelitian ini dimulai dengan bentuk penilaian kemampuan guru, tahap kedua adalah bentuk observasi praktik mengajar, dan tahap ketiga adalah penilaian praktik mengajar siswa. Data kualitatif dikumpulkan dari observasi. Siswa Semester 6 adalah subjek penelitian dan mereka adalah calon guru yang akan mengajar di mata kuliah TEFL. Mereka bergantian menjadi guru dan murid. Peneliti menggunakan alat penilaian untuk melakukan pengamatan atau observasi yang telah dievaluasi melalui penilaian kompetensi guru untuk prosedur pengelolaan kelas. Kemudian, melalui kuesioner evaluasi yang terdiri dari beberapa item evaluasi, peneliti memberikan evaluasi melalui item evaluasi silang.

\section{Teknik Pengolahan data}

Peneliti melakukan observasi langsung ke mahasiswa yang sedang melakukan praktek mengajar di mata kuliah TEFL, kemudian peneliti mencatat dan memeriksa checklist setiap kegiatan yang dilakukan oleh calon guru dalam mengajar. Tugas peneliti juga memberikan catatan dengan melihat beberapa indikator yang diberikan sesuai dengan Rencana pelaksanaan pembelajaran (RPP) yang telah disusun oleh mahasiswa. Berikut pengolahan datanya, melihat hasil 
klasifikasi kinerja mahasiswa berdasarkan Sugiyono (2012) adalah sebagai berikut.

1. Sangat Baik

2. Cukup Baik

3. Kurang baik

4. Sangat tidak baik (1)

Tabel 1. Aspek yang dinilai

\begin{tabular}{|c|c|}
\hline No & $\begin{array}{c}\text { Aspek/Kemampuan yang Dinilai } \\
\text { Pra Pembelajaran }\end{array}$ \\
\hline $\mathbf{I}$ & $\begin{array}{l}\text { Keterampilan dalam menyiapkan } \\
\text { ruang, alat, dan media } \\
\text { pembelajaran } \\
\text { Memeriksa kesiapan peserta didik }\end{array}$ \\
\hline II & $\begin{array}{l}\text { Membuka Pembelajaran } \\
\text { 1. Melakukan kegiatan apersepsi } \\
\text { dan menyampaikan kompetensi/ } \\
\text { tujuan yang akan dicapai dan } \\
\text { rencana kegiatan }\end{array}$ \\
\hline
\end{tabular}

III Kegiatan Inti Pembelajaran

A Penguasaan Materi Pembelajaran
a) Menunjukkan penguasaan materi pembelajaran
b) Mengaitkan materi dengan pengetahuan lain yang relevan
c) Mengintegrasikan kerja ilmiah dalam pembelajaran
d) Menarik kesimpulan menuju penemuan konsep

\section{B. Pendekatan dan Strategi Pembelajaran}

a) Melaksanakan pembelajaran sesuai dengan kompetensi tujuan yang akan dicapai

b) Melaksanakan pembelajaran secara runtun

c) Menguasai Kelas

d) Melaksanakan pembelajaran yang bersifat textbook

e) Melaksanakan pembelajaran yang menumbuhkan sikap positif

f) Melaksanakan pembelajaran alokasi waktu yang direncanakan
C.Pemanfaatan

sumber belajar/media ajar
a) Menunjukkan ketersediaan media dalam pembelajaran
b) Menunjukkan keterampilan dalam penggunaan sumber belajar/media pembelajaran
c) Menghasilkan pesan yang menarik minat peserta didik belajar
d) Melibatkan siswa dalam pembuatan dan pemanfaatan sumber belajar/media pembelajaran

D. Pembelajaran yang memicu dan memelihara keterlibatan kelas
a) Menumbuhkan partisipasi aktif peserta didik melalui interaksi guru, peserta didik, dan sumber belajar
b) Merespons positif partisipasi peserta didik
c) Menunjukkan sikap terbuka terhadap respons peserta didik
d) Menunjukkan hubungan antar pribadi yang kondusif
e) Menumbuhkan keceriaan dan antusiasme peserta didik dalam belajar

E. Penilaian proses dan hasil belajar
a) Memantau kemajuan belajar
b) Melakukan penilaian akhir sesuai dengan kompetensi/ tujuan

\section{F. Penggunaan Bahasa}
a) Menggunakan
Bahasa lisan secara jelas dan lancer
b) Menggunakan bahasa tulis yang baik dan benar
c) Menyampaikan pesan dengan gaya yang sesuai

\section{Penutup}
a) Melaksanakan refleksi atau membuat rangkuman dengan melibatkan siswa 
b) Melaksanakan tindak lanjut dengan memberikan arahan atau kegiatan sebagai bagian dari review

\section{HASIL DAN PEMBAHASAN}

Berdasarkan hasil penelitian yang terkumpul, ada beberapa indikator yang dapat digunakan untuk menilai ketuntasan siswa dalam proses pembelajaran di kelas. Sampel penelitian ini adalah 50 mahasiswa semester 6. Mereka mengambil bahasa Inggris sebagai salah satu mata pelajaran wajib ketika mereka mengajar di depan kelas dan mengajar langsung di sekolah. Indikator berikut akan dijelaskan berdasarkan tabel. Ada beberapa keterampilan mengajar bagi siswa untuk menjadi guru, yang pertama adalah kemampuan untuk melihat, meliputi beberapa indikator, yang kedua adalah kemampuan untuk melakukan kegiatan inti pembelajaran, dan yang terakhir adalah kemampuan untuk mengakhiri pelajaran.

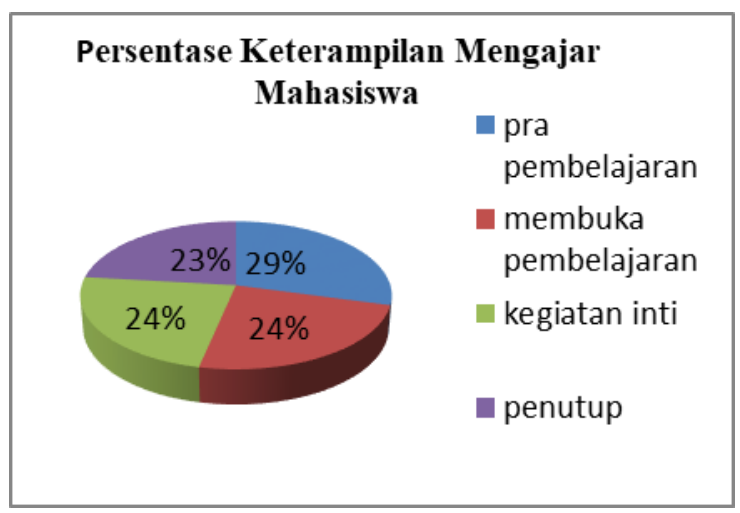

Diagram 1. Persentase keterampilan

Seperti yang terlihat pada Diagram 1, keterampilan mengajar mahasiswa semester 7 merupakan proporsi yang lebih tinggi dari pra-studi, yaitu persiapan bahan dan media pembelajaran, sebesar $29 \%$, diikuti oleh $24 \%$ pembelajaran terbuka, dan kegiatan inti masih di level 24\%, persentase keterampilan pada kegiatan penutupan dalam proses belajar mengajar adalah $23 \%$. Hal ini menunjukkan bahwa keterampilan prasekolah mahasiswa atau calon guru dapat tergolong baik. Kemudian dari segi keterampilan menutup atau closing skill dapat dikategorikan cukup.

Berikut ini hasil berbagai indikator keterampilan mengajar mahasiswa semester tujuh, yaitu:

\section{a. Pra Pembelajaran}

a) Kesiapan ruang, alat, dan media pembelajaran

b) Memeriksa kesiapan peserta didik

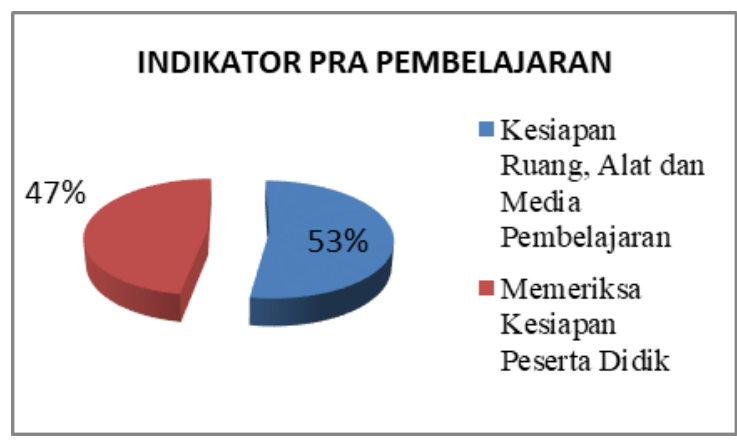

Diagram 2. Indikator pra pembelajaran

Diagram 2 di atas menunjukkan bahwa indikator pra pembelajaran yang terdiri dari kesiapan ruang, alat, dan media pembelajaran memiliki persentase tinggi yaitu 53\% dari 50 mahasiswa atau calon guru. Namun demikian ternyata 50 mahasiswa juga memiliki persentase yang baik dalam memeriksa kesiapan peserta didik sebelum proses pembelajaran berlangsung yaitu $47 \%$. Setiap mahasiswa memiliki keterampilan dan penguasaan mengajar masing-masing. Hal ini terlihat bahwa mahasiswa memiliki tingkat kesiapan yang baik ketika membuka kelas. Baik dari segi kesiapan mental maupun media pembelajaran seperti rencana pelaksanaan pembelajaran, alat menulis, absensi, dan ruang kelas yang nyaman serta kondusif. Ruang kelas yang nyaman akan memberikan efek yang positif bagi peserta didik untuk tetap mengikuti pembelajaran dari awal sampai akhir. 


\section{a. Membuka Pembelajaran}

a) Melakukan kegiatan apersepsi

b) Menyampaikan kompetensi/tujuan yang akan dicapai dan rencana kegiatan

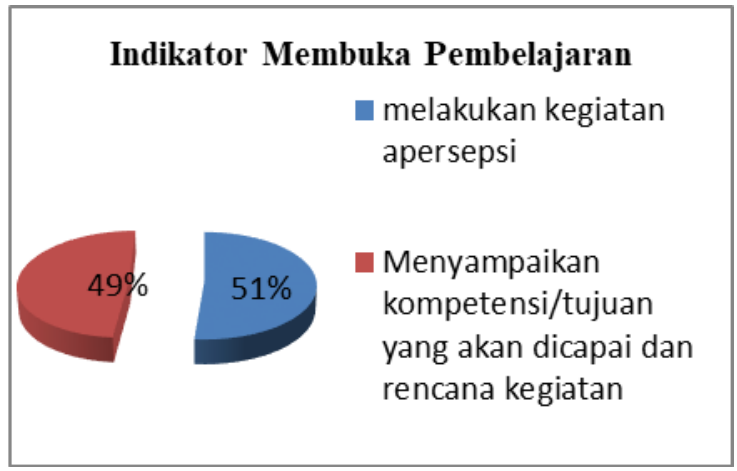

Diagram 3. Indikator membuka Pembelajaran

Berdasarkan Diagram 3 di atas, bahwa indikator membuka pembelajaran yang dilakukan oleh mahasiswa atau calon guru memiliki persentase $51 \%$ untuk melakukan kegiatan apersepsi yaitu kegiatan memotivasi peserta didik dengan memberikan penjelasan tentang pentingnya materi yang akan diajarkan. Sedangkan kegiatan dalam menyampaikan kompetensi/ tujuan yang akan dicapai dan rencana kegiatan pembelajaran $49 \%$. Dapat disimpulkan bahwa keterampilam mahasiswa dalam membuka pelajaran seperti apersepsi dan menyampaikan tujuan pembelajaran tidak terlupa untuk disampaikan sebelum pembelajaran dimulai. Pada saat membuka pelajaran, seorang guru akan memberikan kesan yang baik diawal pembelajaran untuk menghindari terjadinya keributan, rasa tidak nyaman dan memberikan penilaian terhadap guru yang tidak pandai mengajar.

\section{b. Kegiatan Inti Pembelajaran}

a) Penguasaan materi pembelajaran

b) Pendekatan dan strategi pembelajaran

c) Pemanfaatan sumber belajar/media pembelajaran

d) Pembelajaran yang memicu dan memelihara keterlibatan kelas e) Penilaian proses dan hasil belajar

f) Penggunaan bahasa

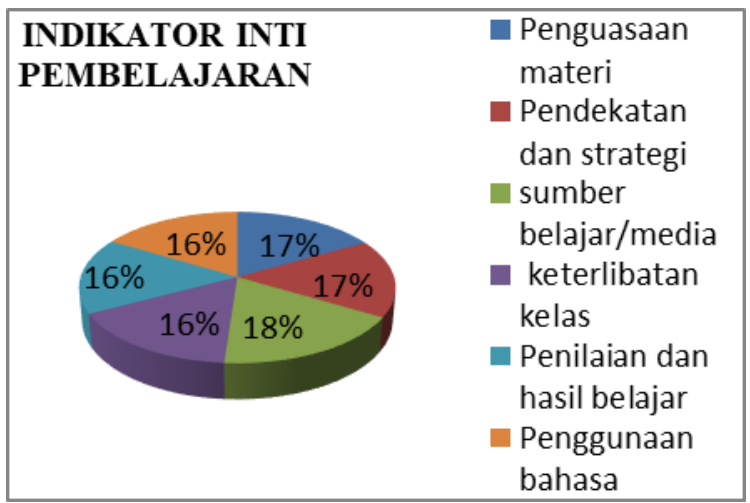

Diagram 4. Indikator inti pembelajaran

Berdasarkan Diagram 4, ada beberapa indikator inti untuk dipelajari siswa atau calon guru, pertama adalah kemampuan penguasaan materi pembelajaran 17\%, hal ini seperti kemampuan dalam menyampaikan materi yang diajarkan. Kemudian metode dan strategi pembelajaran $17 \%$, metode dan strategi pembelajaran juga tidak dapat terpisahkan dalam keberhasilan seorang guru di dalam kelas. Selanjutnya tingkat pemanfaatan sumber belajar/media pembelajaran $18 \%$, sumber belajar dan media pembelajaran yang bervariasi akan memberikan ketertarikan kepada peserta didik untuk lebih dapat memahami pembelajaran. Kemudian selain itu juga sumber belajar memicu dan mempertahankan partisipasi kelas dalam pembelajaran.

Proses pembelajaran yang melibatkan peserta didik untuk dapat berpartisipasi sebesar 16\%, sedangkan untuk evaluasi proses dan hasil belajar sebesar 16\%, dan penggunaan bahasa komunikatif sebesar 16\%, bahasa komunikatif dapat kita ucapkan dengan melihat level peserta didik. Dapat disimpulkan bahwa pada kegiatan inti, salah satu kunci kesuksesan seorang guru dalam mengajar, karena akan terlihat bagaimana calon guru dapat menyampaikan materi pembelajaran dengan baik dan menyenangkan. Selain dari kemampuan menyampaikan materi, 
terdapat juga kemampuan calon guru atau mahasiswa dalam mengkondisikan suasana di dalam kelas supaya peserta didik dapat mengikuti pembelajaran dengan baik dan merasa tidak bosan di dalam kelas. Inilah yang menjadi kesuksesan seorang guru di dalam kelas.

\section{c. Penutup}

a) Melakukan refleksi atau membuat rangkuman dengan melibatkan siswa

b) Melaksanakan tindak lanjut dengan memberikan arahan dan kegiatan atau tugas

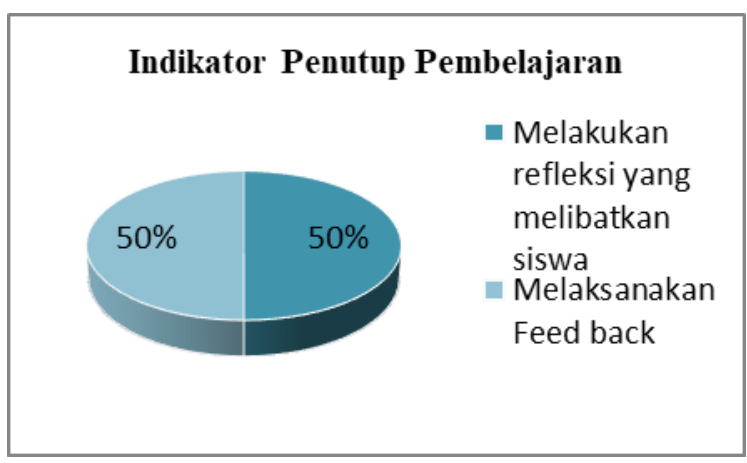

Diagram 5. Indikator penutup

Mengacu kepada Diagram 5 di atas, kegiatan terakhir adalah mengakhiri pembelajaran, seperti melibatkan $50 \%$ siswa dalam refleksi atau rangkuman, dan menindaklanjuti dengan memberikan arahan dan kegiatan atau $50 \%$ pekerjaan rumah. Artinya, dalam kegiatan 50 siswa ini, 25 orang akan melakukan refleksi atau rangkuman di akhir kursus, dan 25 orang atau lainnya akan mengerjakan atau memberikan pekerjaan rumah. Jadi tidak semua siswa melakukan kedua kegiatan tersebut pada indikator akhir pembelajaran.

Pada keterampilan menutup pelajaran, calon guru dapat memberikan kesimpulan materi yang telah diajarkan sehingga peserta didik dapat dengan mudah memahami. Peserta didik dapat kita libatkan seperti halnya menjawab pertanyaan yang diberikan oleh seorang guru. Seorang guru dapat mengukur keberhasilan peserta didik dalam memahami kemampuan dalam menyerap materi yang telah diberikan oleh seorang guru. Selain itu ketertarikan seorang peserta didik dengan pembelajaran yang telah diberikan menjadi salah satu feedback bagi guru untuk memperbaiki kegiatan pembelajaran di masa yang akan datang.

\section{Pembahasan}

Menurut hasil penelitian Sutisnawati (2017) yang berjudul "Analisis Keterampilan Dasar Mengajar Guru dan Siswa Sekolah Dasar Masa Depan", hasil penelitian meliputi tujuh keterampilan dasar mengajar siswa yang diamati dan dianalisis dalam pelaksanaan magang, antara lain 1). Membuka kelas keterampilan, 2). Keterampilan penguasaan materi, 3). Menerapkan interaksi pembelajaran dalam skenario pembelajaran, 4). Penggunaan bahasa, 5). Alokasi waktu, 6). Evaluasi pembelajaran, 7) Keterampilan akhir pembelajaran. Tujuh keterampilan dasar mengajar mahasiswa PGSD dalam keseluruhan pelaksanaan Magang II sudah baik, dengan tingkat penilaian 76,81\%.

Keterampilan dasar mengajar siswa PGSD dengan standar baik adalah memulai kelas $(84,86 \%)$, menerapkan interaksi pembelajaran dalam skenario pembelajaran $(82,89 \%)$, penggunaan bahasa $(83,55 \%)$ dan evaluasi pembelajaran $(86,84 \%)$. Keterampilan penguasaan materi adalah standar yang baik, dan keterampilan akhir pembelajaran serta alokasi waktu sudah cukup. Hal ini juga dilakukan oleh tim peneliti melalui analisis empat indikator yaitu pra pembelajaran, pembelajaran terbuka, kegiatan inti dan mata kuliah penutup. Karena tingkat penguasaan setiap siswa juga berbeda. Berdasarkan hasil penelitian, proporsi terbesar keterampilan mengajar siswa adalah pra pembelajaran, yaitu $29 \%$ yang tergolong baik, dan untuk kategori cukup yaitu keterampilan tertutup sekitar 23\%. Dapat disimpulkan bahwa keterampilan mengajar siswa tergolong 
baik dalam pembelajaran terbuka, yang juga terjadi pada penelitian sebelumnya yang dilakukan oleh Sutisnawati.

Sedangkan hasil penelitian yang dilakukan oleh Herdi, Abbas, \& Kasriyati (2021) tentang analisis kemampuan mahasiswa dalam sistem pengelolaan Micro Teaching dengan siklus Perencanaan, Pelaksanaan, Evaluasi, Pengendalian, Peningkatan (PPEPP) menggambarkan bahwa pengelolaan kelas Micro Teaching pada setiap indikator siklus PPEPP adalah 62.55 yang dapat dikategorikan cukup. Ini artinya kemampuan mahasiswa cukup mampu menerapkan keterampilan dalam mengajar. Dari penelitian yang dilakukan oleh Herdi, dkk (2021) tersebut, dapat diambil perbedaan yaitu pada mata kuliah yang berbeda dan indikator-indikator yang diteliti juga berbeda tetapi memiliki kesamaan dalam hasil yang diperoleh.

Menurut Supriyadi, Bahri, \& Waremra (2018) yang meneliti tentang kemampuan Technological Pedagogical and Content Knowledge (TPACK), bahwa melalui pembelajaran strategi belajar mengajar Fisika, kemampuan TPACK mahasiswa tersebut menjadi meningkat. Dari penelitian ini juga dapat disimpulkan perlu adanya penelitian lanjutan untuk mengetahui faktor-faktor yang memengaruhi kemampuan TPACK mahasiswa calon guru.

\section{KESIMPULAN}

Berdasarkan hasil penelitian yang ada, proporsi keterampilan praktik mengajar siswa berbeda-beda, setiap keterampilan mengajar dapat diklasifikasikan sebagai keterampilan pra belajar yang cukup tinggi, yaitu tingkat kesiapan siswa untuk menyiapkan berbagai media pembelajaran yang menarik untuk mengajar. Dalam memfasilitasi proses pembelajaran supaya beroperasi secara efektif, mahasiswa yang ingin mengajar, mereka harus memperhatikan persiapannya, dan siswa yang akan diajar melalui inspeksi hadir. Hal ini sangat baik dan dapat memberikan stimulasi awal sebelum dimulainya pembelajaran. Pada dasarnya, siswa mampu menerapkan keterampilan mengajar sesuai dengan komponennya.

Sedangkan hasil penelitian dari Sukmawati (2019) bahwa mahasiswa program studi pendidikan matematika pada mata kuliah microteaching sudah mampu menjadi guru profesional berdasarkan kompetensi pendidik yaitu kompetensi pedagogik, kepribadian, profesional dan sosial.

Sementara hasil penelitian Mukhibad \& Susilowati (2010) bahwa keberhasilan praktek mengajar mahasiswa sangat dipengaruhi oleh peran seorang pamong, dosen, kualitas keterampilan dalam mengajar dan peranan antar siswa yang diajarkan. Sehingga dapat disimpulkan bahwa kesuksesan mahasiswa dalm praktek mengajar memiliki andil dari berbagai pihak tidak hanya pada mahasiswa yang bersangkutan. Tidak dapat dipungkiri hal ini memang akan saling mendukung dari keberhasilan calon guru dalam mengajar. Seperti halnya seorang pamong yang akan terus memberikan perbaikan ketika calon guru praktek mengajar di dalam kelas, sehingga calon guru dapat menjadi lebih baik dalam mengajar. Begitu pula dengan seorang dosen yang memiliki keterlibatan dalam kesuksesan seorang calon guru, karena secara teori calon guru sudah diajarkan bagaimana menjadi seorang guru yang profesional.

\section{DAFTAR PUSTAKA}

Armansyah. L, Hanafi dan Adawiyah Rabiatul (2019). Sistem Pengelolaan Microteaching dengan Siklus Perencanaan, Pelaksanaan, Evaluasi, Pengendalian, Peningkatan (PPEPP) untuk Meningkatkan Keterampilan mengajar Mahasiswa Calon Guru. Padang: CV Berkah Prima.

Helmiati. (2013). Micro Teaching. Yogyakarta: Aswaja Pressindo.

Herdi, H., Abbas, M. F. F., \& Kasriyati, D. (2021). Analisis Kemampuan 
Mahasiswa dalam Sistem Pengelolaan Microteaching dengan Siklus Perencanaan, Pelaksanaan, Evaluasi, Pengendalian, Peningkatan (PPEPP). Jurnal Pendidikan, 9(1), 11-21.

Maheswari, V.K. (2011). Micro-Teaching: A Scaled-down, Simulated Practice Teaching Technique. Diakses dari http://www.vkmaheshwari.com/WP/? $\mathrm{p}=173$ (Tanggal 7 September 2019).

Mukhibad, H., \& Susilowati, N. (2010). Studi evaluasi kompetensi mengajar mahasiswa praktek pengalaman lapangan (PPL) Jurusan Akuntansi Universitas Semarang. Lembaran Negeri Kependidikan, 39(2).

Saragih, A. H. (2008) Kompetensi Minimal Seorang Guru Dalam Mengajar. Jurnal Tabularasa, 5 (1). pp. 23-34.

Shoffa. S. (2017). Keterampilan Dasar Mengajar Micro Teaching. Surabaya: Mavendra Pers.

Sugiyono. (2012). Metode Penelitian Kuantitatif Kualitatif dan $R \& B$. Bandung: Alfabeta.

Sukmawati, R. (2019). Analisis kesiapan mahasiswa menjadi calon guru profesional berdasarkan standar kompetensi pendidik. Jurnal Analisa, 5(1), 95-102.

Supriyadi, S., Bahri, S., \& Waremra, R. S. (2018). Kemampuan Technological Pedagogical Content Knowledge (TPACK) Mahasiswa Pada Matakuliah Strategi Belajar Mengajar Fisika. Jurnal Inspirasi Pendidikan, 8(2), 1-9. https://doi.org/10.21067/jip.v8i2.263

2.

Sutisnawati. A. (2017). Analisis Keterampilan Dasar Mengajar Mahasiswa Calon Guru Sekolah Dasar. $M P D, 8(1)$.

Suwarna, dkk. (2006). Pengajaran Mikro Pendekatan Praktis dalam menyiapkan pendidik profesional. Yogyakarta: Tiara Wacana.
Undang-Undang Nomor 14 Tahun 2005 tentang Guru dan Dosen.

Uno, H. (2012). Profesi Kependidikan: Problema, Solusi dan Reformasi Pendidikan di Indonesia. Jakarta: Bumi Aksara

Yenni, Y. (2017). Analisis Kemampuan Mahasiswa dalam Menyiapkan Pembelajaran yang Efektif pada Mata Kuliah SBMM." JPPM (Jurnal Penelitian dan Pembelajaran Matematika) 10(2). 